\title{
ANALISIS HASIL TANGKAPAN RAKANG DAN BUBU PADA PERCOBAAN PENANGKAPAN KEPITING DI PERAIRAN MANGROVE MALUKU
}

\author{
Isa Nagib Edrus" dan Amran Ronny Syam")
}

\begin{abstract}
ABSTRAK
Percobaan penangkapan kepiting telah dilakukan di perairan bakau Teluk Kotania Seram Barat dan Teluk Kayeli Pulau Buru, Maluku. Kegiatan ini menggunakan alat tangkap rakang dan bubu. Tujuan dari penelitian ini adalah untuk mendapatkan data hasil tangkapan, ukuran berat, produksi, produktivitas alat tangkap, dan perbandingan hasil ke dua alat tangkap tersebut. Jenis-jenis kepiting hasil tangkapan adalah kepiting kaniki (Thalmita danae), rajungan (Portunus pelagicus), kepiting bakau merah (Scylla serrata), kepiting bakau hitam (Scylla oceanica), dan kepiting bakau hijau (Scylla tranquebarica). Sebagian besar hasil tangkapan rakang adalah berukuran kecil ( $70 \%$ berukuran di bawah $150 \mathrm{~g}$ ), sedangkan hasil tangkapan bubu untuk ukuran yang sama hanya $30 \%$. Hasil tangkapan rakang dalam 64 hari operasi penangkapan adalah 378 ekor atau setara dengan $62,6 \mathrm{~kg}$. Berat rata-ratanya adalah $172 \pm 185 \mathrm{~g}(\mathrm{~N}=378)$. Sebaliknya, produksi dari bubu dalam 23 hari operasi penangkapan adalah 132 ekor atau setara dengan $42,64 \mathrm{~kg}$. Berat rata-ratanya adalah $353 \pm 230 \mathrm{~g}$ $(\mathrm{N}=132)$. Rata-rata hasil tangkapan per unit upaya untuk rakang adalah $17 \mathrm{~g} / \mathrm{unit}$ alat/trip/nelayan, sedangkan untuk bubu adalah $120 \mathrm{~g} / \mathrm{unit}$ alat/trip/nelayan.
\end{abstract}

\section{ABSTRACT: An analysis of stick dip net's and pot's catches in the crab fishing trial in mangrove water of Maluku. By: Isa Nagib Edrus and Amran Ronny Syam}

Crab fishing trials were carried out in mangrove waters of Kotania Bay West Seram and Kayeli Bay of Buru Island in Maluku. Stick dip net and trap pot used in this trial aimed to obtain data of catches including crab species, weight sizes, gear productivity, and their comparative yields. Crab species identified during the fishing trial were kaniki (Thalmita danae), rajungan (Portunus pelagicus), red-mud crab (Scylla serrata), black-mud crab (Scylla oceanica) and geen-mud crab (Scylla tranquebarica). The majority of the crabs caught by stick dip nets was small size (70\% under $150 \mathrm{~g}$ ); however, the similar size crabs caught by pots was only $30 \%$. The yield produced by stick dip nets during 64-day fishing trips was 378 individuals or equivalent to $62.6 \mathrm{~kg}$. Its weight average is $172 \pm 185 \mathrm{~g}(\mathrm{~N}=378)$. On the other hand, the production of pots during 23-day fishing trip was 132 individuals or equivalent to $42.64 \mathrm{~kg}$. Its weight average is $353 \pm 230 \mathrm{~g}(N=132)$. Catch per Unit of Effort average of stick dip nets was $17 \mathrm{~g} / \mathrm{gear} / \mathrm{trip} / \mathrm{pperator}$, where as the CPUE average of pots was $120 \mathrm{~g} /$ gear/trip/operator.

KEYWORD: $\quad$ stick dip nets, trap pots, gear productivity, mud crab, Maluku

\section{PENDAHULUAN}

Kepiting bakau (Scylla serrata Forska) merupakan salah satu komoditas ekspor dengan negara tujuan seperti Hongkong, Singapura, dan Jepang (Anonimous, 1989; Yunus, 1992). Untuk pengembangan perikanan kepiting bakau ke arah ekspor diperlukan dukungan kontinuitas produksi, yang karenanya pengembangan teknologi produksi termasuk pascapanen merupakan hal yang semestinya dirintis untuk menjawab tantangan dari luasnya wilayah tangkapan kepiting bakau di Maluku.

Luas keseluruhan hutan bakau di Maluku adalah sekitar 100 ribu ha (Nontji, 1987). Potensi lahan bakau ini jelas memberikan peluang dalam diversifikasi usaha perikanan pesisir pantai. Usaha perikanan kepiting bakau yang telah berkembang terutama ditemukan di Pulau Buru dan sekitar Teluk Kotania Seram Barat. Usaha ini secara intensif sudah berlangsung selama dua dekade terakhir dengan produksi berkisar antara $800 \mathrm{~kg}$ per minggu per sentra produksi (Edrus \& Bustaman, 1998).

Perluasan wilayah penangkapan kepiting bakau jarak jauh membutuhkan teknologi tepat guna. Luasnya area mangrove tersebut selain membutuhkan suatu alat tangkap yang sederhana dan praktis dalam arti ringan, mudah ditransportasikan dan mudah digunakan, juga memberikan hasil tangkapan yang tinggi.

Umumnya kepiting bakau di Maluku ditangkap dengan bubu dan gancu, sedangkan di tempat lain seperti Kalimantan dikenal alat tangkap lain yang disebut ambau dan dakang-dakang atau rakang (Afrianto \& Liviawati, 1992; Wardoyo et al., 1996). Kedua alat yang terakhir ini cukup berhasil meningkatkan produksi, terutama di Kalimantan dan Sulawesi. Di Maluku, alat tangkap yang disebut rakang kurang begitu populer atau dikenal. Menurut Subani (1972), jaring rakang yang hanya

Peneliti pada Balai Pengkajian Teknologi Pertanian Maluku 
menggunakan seutas tali untuk houling disebut crab lift net, dan yang menggunakan tongkat disebut stick dip net.

Alat tangkap rakang ini belum disosialisasikan kepada nelayan di Maluku, sehingga upaya diversifikasi alat tangkap kepiting perlu dukungan pengkajian adopsi, baik dari aspek sosial, teknis, biologi maupun lingkungan. Sebagai bagian dari pengkajian adopsi yang telah dilaksanakan oleh Balai Pengkajian Teknologi Pertanian Maluku, penelitian ini lebih memusatkan perhatian pada aspek teknis dan percobaan penangkapan kepiting dengan rakang di lapangan, karena keberhasilan introduksi alat tangkap tersebut pada suatu masyarakat nelayan bergantung pada informasi aplikatif alat tangkap tersebut.

Tanggapan masyarakat setempat terhadap teknologi anjuran seringkali menunggu atau melihat contoh keberhasilan pemanfaatannya pada berbagai percobaan di wilayah yang sama. Informasi aplikasi alat tangkap rakang di Maluku belum diketahui, karena dibanding bubu alat rakang kurang begitu dikenal.

Untuk membangun hipotesa kerja bagi promosi alat tangkap rakang, sifat-sifat rakang seperti jenis tangkapan, produksi, produktifitas, dan perbandingannya dengan bubu perlu diidentifikasi. Penelitian ini mencoba untuk menghimpun hasil aplikasi ke dua jenis alat tangkap kepiting tersebut di perairan bakau Teluk Kotania dan Teluk Kayeli. Analisis hasil semata-mata bersandar pada hasil percobaan penangkapan yang dilakukan bersama nelayan berdasarkan pada pola penangkapan yang biasa mereka lakukan. Sehingga percobaan ini tidak didukung oleh rancangan yang terlalu bersifat ilmiah.

Tujuan penelitian ini adalah untuk
mengindentifikasi jenis kepiting bakau yang
tertangkap, ukuran bobot badan, produksi, dan cacth
per unit of effort dari alat tangkap rakang serta
membandingkan dengan hasil tangkapan dari bubu.

\section{BAHAN DAN METODE}

Lokasi kegiatan penangkapan tersebar di 14 daerah penangkapan, yaitu meliputi hutan bakau wilayah Desa Wael, Masikajaya, Tamanjaya, Kotania Teluk Kotania, Kecamatan Piru Seram Barat dan Kakiair, Teluk Kayeli Kecamatan Namlea, Buru Utara Timur. Kegiatan berlangsung antara bulan Agustus sampai dengan Nopember 1997.

\section{Tipe Alat Tangkap}

Ada dua jenis alat yang digunakan untuk penelitian ini, yaitu rakang dan bubu. Rakang terdiri dari tiga bagian (Gambar 1), yakni bingkai rotan dengan diameter $50 \mathrm{~cm}$, yang padanya dirajut tali nilon multifilamen sehingga membentuk model jala kerucut.
Jala berbingkai rotan ini dioperasikan dengan menggunakan tongkat kayu dengan diameter $2 \mathrm{~cm}$ dan panjang 2 meter. Tongkat ini dilengkapi dengan penjepit umpan dari bahan bambu yang diris tipis 2-3 $\mathrm{mm}$ dengan panjang $30 \mathrm{~cm}$. Penjepit tersebut diikat kira-kira $30 \mathrm{~cm}$ dari ujung tongkat yang lancip (bagian yang akan ditancapkan pada substrat). Pada saat alat tangkap ini akan digunakan, tongkat ini dimasukan di bagian pusat jala yang berbentuk cincin (diameter 2,5 $\mathrm{cm}$ ), sehingga penjepit umpan tertahan pada cincin jala, sementara bingkai rotan akan menempel kuat pada tongkat dengan bantuan 3 alur tali yang membuat jala meregang kencang. Sedangkan bubu yang digunakan adalah bubu bambu berpintu satu dengan diameter $25 \mathrm{~cm}$. Ukuran badan bubu adalah tinggi $35 \mathrm{~cm}$, lebar $50 \mathrm{~cm}$, dan panjang $100 \mathrm{~cm}$ (atau $\left.0,175 \mathrm{~m}^{3}\right)$.

\section{Jenis Umpan}

Umpan yang digunakan adalah ikan berdaging liat dan amis seperti cucut, hiu atau belut. Potongan umpan diselipkan pada penjepit bambu yang terikat pada tongkat. Umpan diselipkan kira-kira $10-15 \mathrm{~cm}$ di atas jala.

\section{Operasional Alat Tangkap}

Pendekatan yang digunakan dalam percobaan ini adalah skala operasional menurut cara-cara yang dilakukan oleh nelayan setempat dalam menangkap kepiting bakau. Pengoperasian rakang menggunakan perahu kecil. Untuk transportasi antar lokasi menggunakan perahu bermotor yang relatif lebih besar. Untuk membandingkan hasil tangkapan rakang dengan hasil bubu, operasi penangkapan dengan rakang dilakukan bersamaan dengan operasi penangkapan dengan bubu pada daerah penangkapan yang sama. Rakang yang berbentuk jala kerucut ditancapkan dengan posisi miring pada dasar perairan, sehingga satu sisi bingkai rotan menyentuh substrat (Gambar 1).

Dalam satu kali tawur (setting) digunakan 30, 40, dan 50 unit rakang dalam satu armada penangkapan yang terdiri atas 1 sampai 3 orang nelayan. Rakang dioperasikan pada saat menjelang air pasang hingga air pasang penuh. Proses ini memakan waktu 3-4 jam setiap periode pasang surut. Selama periode tersebut dapat dilakukan pengangkatan rakang (hauling) apabila ada tanda-tanda tongkat rakang bergerakgerak yang menunjukkan kepiting sedang memakan umpan. Setelah diangkat, rakang dipasang lagi di sekitar daerah tersebut. Hal ini dilakukan berulang kali selama periode menjelang pasang hingga pasang penuh. Sifat aktif dari penggunaan alat rakang ini terletak pada saat pengangkatan alat dan pemasangan kembali, karena bila tidak diangkat maka besar kemungkinan kepiting akan keluar dari jala.

Pola pemasangan bubu (setting) adalah sistem antar jemput yaitu pembenaman bubu ke dalam 


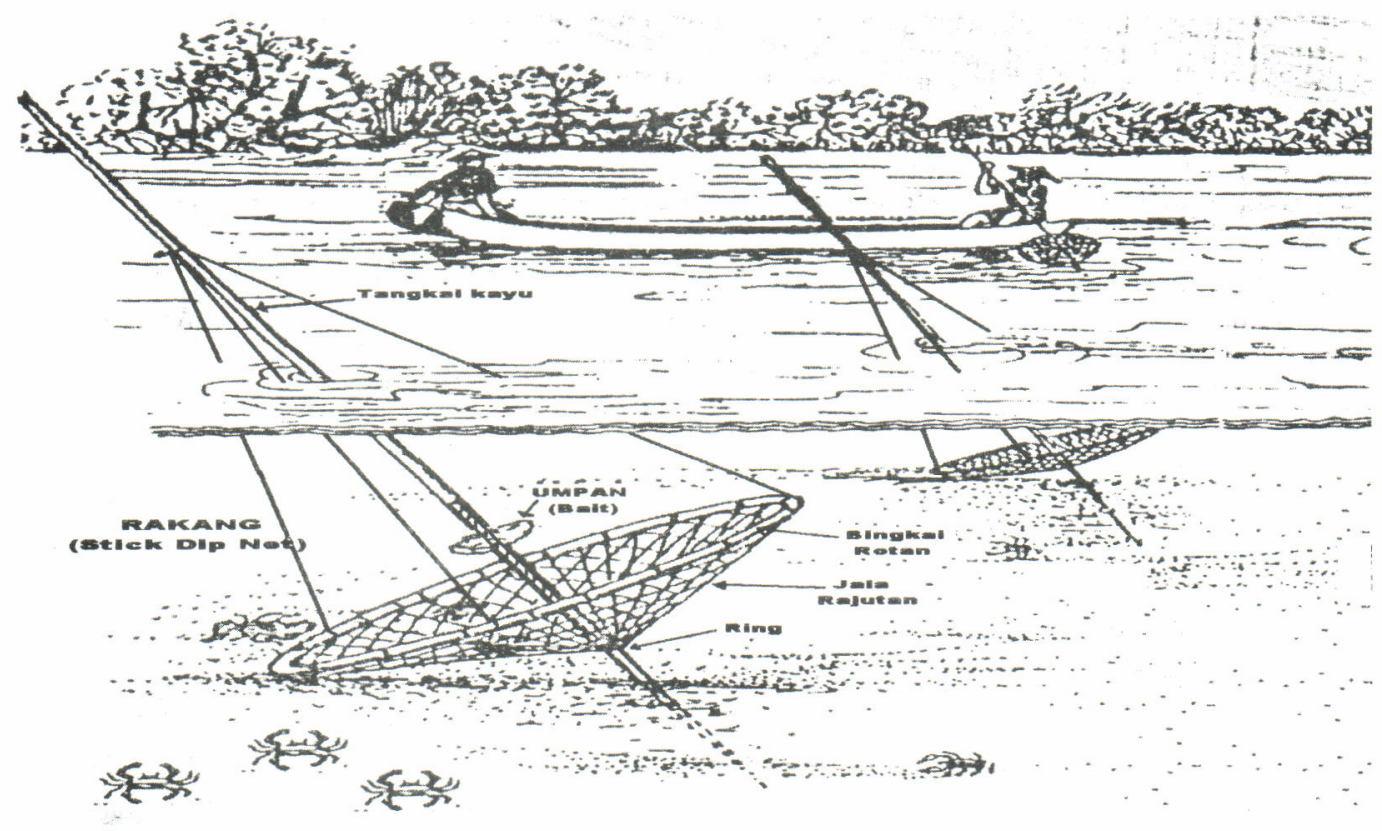

Gambar 1. Alat tangkap kepiting bakau "rakang".

Figure 1. A mud crab fishing gear (stick dip net).

perairan pada siang hari, kemudian pengangkatan bubu pada esok harinya. Jadi bubu terpasang selama 24 jam dengan interval beberapa menit untuk mengambil hasil dan mengganti umpan. Pemeriksaan atau pergantian umpan pada bubu dilakukan setelah periode pengoperasian rakang selesai.

\section{Pengumpulan Data}

Data jenis kepiting dihimpun dengan mengunakan buku penuntun identifikasi jenis kepiting (Moosa, 1980; Moosa et al., 1985). Ukuran tubuh, khususnya berat badan kepiting (satuan gram), diambil dengan cara menimbangnya dengan timbangan O-hous dengan tingkat ketelitian 0,1 gr. Data produksi untuk menghitung Cacth per Unit of Effort (CPUE) dihimpun melalui penimbangan hasil dan dikelompokkan menurut jumlah alat tangkap, hari operasi (trip), dan jumlah nelayan.

\section{Analisis Data}

Analisis data hasil tangkapan lebih bersifat deskriptif berupa penyajian nilai tertinggi, terendah, rata-rata, nilai tengah, dan frekuensi sebaran berat badan kepiting yang diilustrasikan dengan menggunakan bentuk grafik. Hasil produksi selain ditabulasikan menurut jenis tangkapan, alat tangkap dan lokasi penangkapan, juga dianalisis dengan menghitung Catch per Unit of Effort-CPUE (Sparre dan Venema, 1992), di mana CPUE=Total Produksi/jumlah alat/jumlah hari operasi/jumlah nelayan. Perbandingan hasil tangkapan atau kapasitas antara rakang dan bubu dilakukan dengan membandingkan nilai CPUE-nya masing-masing, di mana jenis alat yang memiliki nilai CPUE lebih besar berarti lebih produktif

\section{HASIL DAN BAHASAN}

\section{Jenis Tangkapan}

Dari kegiatan penangkapan kepiting dengan penggunaan rakang dan bubu, baik di desa Wael dan sekitarnya maupun di Kakiair, diperoleh tiga jenis kepiting bakau (Scylla spp.). Selain tiga jenis tersebut, diperoleh juga satu jenis kepiting kaniki (Thalamita danae) yang merupakan hasil tangkapan rakang di Wael dan sekitarnya, yaitu kepiting berukuran kecil yang tidak komersial dan juga satu jenis rajungan (Portunus pelagicus) dari hasil tangkapan rakang di luar perairan bakau Kakiair, Namlea (Tabel 1).

Jenis kepiting bakau yang teridentifikasi adalah kepiting bakau berwarna merah (Scylla serrata), hitam (Scylla oceanica) serta kepiting bakau hijau (Scylla tranquebarica). Marga Scylla yang terdiri dari tiga jenis dianggap sebagai satu jenis yaitu Scylla serrata. Perbedaan dalam warna dianggap sebagai variasi individu dalam penyesuaian terhadap habitat (Moosa et al., 1985)

Dalam perdagangan, kepiting bakau yang berwarna hitam merupakan jenis yang paling disukai oleh eksportir, karena ukurannya relatif besar dibandingkan dengan dua jenis lainnya dan memiliki daya tahan hidup yang tinggi pada saat ditransportasikan.

Kepiting kaniki tidak diperjual-belikan dan hampir tidak pernah dijumpai di pasar setempat. Hal ini 
Tabel 1. Jenis-jenis kepiting dan rajungan yang tertangkap menurut alat tangkap dan lokasi penangkapan selama percobaan penangkapan dengan rakang dan bubu

Table 1. The crab species cought during fishing trials by gears and fishing grounds

\begin{tabular}{lll}
\hline $\begin{array}{c}\text { Alat Tangkap } \\
\text { (Gears) }\end{array}$ & \multicolumn{1}{c}{$\begin{array}{c}\text { Jenis Tangkapan } \\
\text { (Crab Species) }\end{array}$} \\
\hline . Bubu dan Rakang & $\begin{array}{l}\text { kepiting bakau merah (Scylla serrata) } \\
\text { kepiting bakau hitam (Scylla oceanica) } \\
\text { kepiting bakau hijau (Scylla tranquebarica) }\end{array}$ & $\begin{array}{l}\text { Lokasi Penangkapan } \\
\text { (Fishing Grounds) }\end{array}$ \\
& kepiting kaniki (Thalamita danae) & $\begin{array}{l}\text { Warat dsk. Teluk Kotania, Seram } \\
\text { Kakiair (mangrove), Teluk Kayeli, } \\
\text { Pulau Buru }\end{array}$ \\
Rakang & kepiting rajungan (Portunus pelagicus) & Wael dsk. Teluk Kotania, Seram \\
& & Barat \\
Rakang & & Kakiair (karang), Teluk Kayeli, \\
\end{tabular}

disebabkan ukurannya yang kecil sehingga daging yang bisa dimakan terlampau sedikit. Menurut Moosa (1980), kepiting kaniki tidak beracun dan hasil lumatan/rebusan dagingnya dapat dijadikan kaldu sup. Selain itu disebutkan pula bahwa genus Thalamita yang ditemukan di Indonesia memang selalu dalam ukuran kecil, tidak lebih dari $7,5 \mathrm{~cm}$ lebar karapasnya. Kaniki sering dianggap sebagai juvenil atau anak kepiting dari genus Scylla, karena kaniki hampir tidak bisa dibedakan dengan anakan Scylla spp.

Dari cara pengoperasian bubu dan rakang, bubu bersifat pasif sedangkan rakang bersifat aktif dan lebih praktis bila dibawa ke tempat lain, baik di perairan dalam hutan mangrove maupun di luar hutan mangrove (seperti di daerah lamun atau karang). Sifat aktif dari alat rakang ini, seperti telah disebutkan di muka, terletak pada proses pengoperasiannya, yaitu dapat dilakukan beberapa kali tawur (setting) dan beberapa kali pengangkatan (hauling) selama periode menjelang air pasang hingga pasang penuh. Jika tidak ingin kehilangan hasil tangkapan, penggunaan alat rakang mengharuskan adanya pengawasan aktif nelayan selama periode tersebut. Alat rakang dengan ukuran mata jala yang kecil dapat menjaring bukan saja kepiting bakau, tetapi juga kepiting karang atau rajungan dan kepiting berukuran tubuh kecil seperti kaniki. Di berbagai perairan Indonesia, alat tangkap rakang dan sejenisnya sering digunakan untuk menangkap jenis-jenis kepiting lain yang ada di perairan dalam, karang dan lamun, seperti misalnya berbagai jenis rajungan dan lobster (Subani \& Barus, 1989).

Dengan demikian aplikasi alat tangkap rakang ini tidak terbatas pada perairan bakau saja atau pada satu jenis tangkapan saja. Masalahnya sekarang, apakah aplikasi rakang ini, yang menuntut nelayan lebih aktif, mampu mendorong atau merubah kebiasaan nelayan yang gemar pada bubu karena bersifat pasif dalam pengoperasiannya. Aplikasi kedua alat tangkap tersebut pada suatu perairan dapat dianjurkan dengan memanfaatkan rakang sebagai operasi penangkapan yang pokok dan bubu dapat menjadi sampingan. Dengan demikian, nelayan dapat memanfaatkan waktu senggang untuk pengoperasian rakang setelah meletakan bubu di perairan sehingga penangkapan kepiting dapat lebih maskimal, lebih efektif, dan efisien.

Ditinjau dari beragamnya target jenis tangkapan dan kelestarian lingkungan, penggunaan rakang pada perairan karang akan lebih baik dibanding penggunaan bubu. Penggunaan bubu pada perairan karang banyak dikeluhkan pengamat lingkungan karena sifatnya yang dapat merusak terumbu karang, misalnya kebiasaan membongkar karang untuk menyisipkan bubu, sedangkan pengoperasian rakang cukup dengan menancapkan tongkat di sela-sela karang.

\section{Ukuran Berat Badan}

Distribusi frekuensi berat badan kepiting bakau dari hasil tangkapan rakang dan bubu di Wael dan sekitarnya masing-masing dapat dilihat dalam bentuk grafik batang pada Gambar 2.

Variasi berat badan kepiting hasil tangkapan rakang, baik kepiting bakau maupun kaniki, berkisar antara 18-924 g/ekor dengan rata-rata $177 \pm 187 \mathrm{~g}$ $(\mathrm{N}=378)$. Jika dipisahkan jenisnya maka berat badan Scylla spp. adalah $306 \pm 135 \mathrm{~g}(\mathrm{~N}=162)$ dan kaniki (Thalamita danae) adalah $46 \pm 6 \mathrm{~g}(\mathrm{~N}=193)$, sedangkan variasi ukuran berat badan kepiting bakau dari hasil tangkapan dengan bubu adalah 66-1.349 g/ekor, di mana berat rata-ratanya adalah $353 \pm 230 \mathrm{~g}(\mathrm{~N}=132)$.

Distribusi frekuensi berat badan kepiting bakau dan rajungan dari hasil tangkapan rakang di Kakiair diperlihatkan dengan grafik batang pada Gambar 3 .

Hasil tangkapan dengan rakang di Kakiair Namlea rata-rata berukuran lebih kecil dari pada kepiting bakau dari hasil tangkapan rakang di Wael dan sekitarnya. Dari 11 ekor kepiting bakau hasil tangkapan di Kakiair memiliki rata-rata berat badan $250 \pm 125 \mathrm{~g}$ dengan berat badan minimal $112 \mathrm{~g}$ dan maksimal $515 \mathrm{~g}$. Jenis lain yang tertangkap oleh rakang di Kakiair adalah 12 ekor kepiting rajungan 

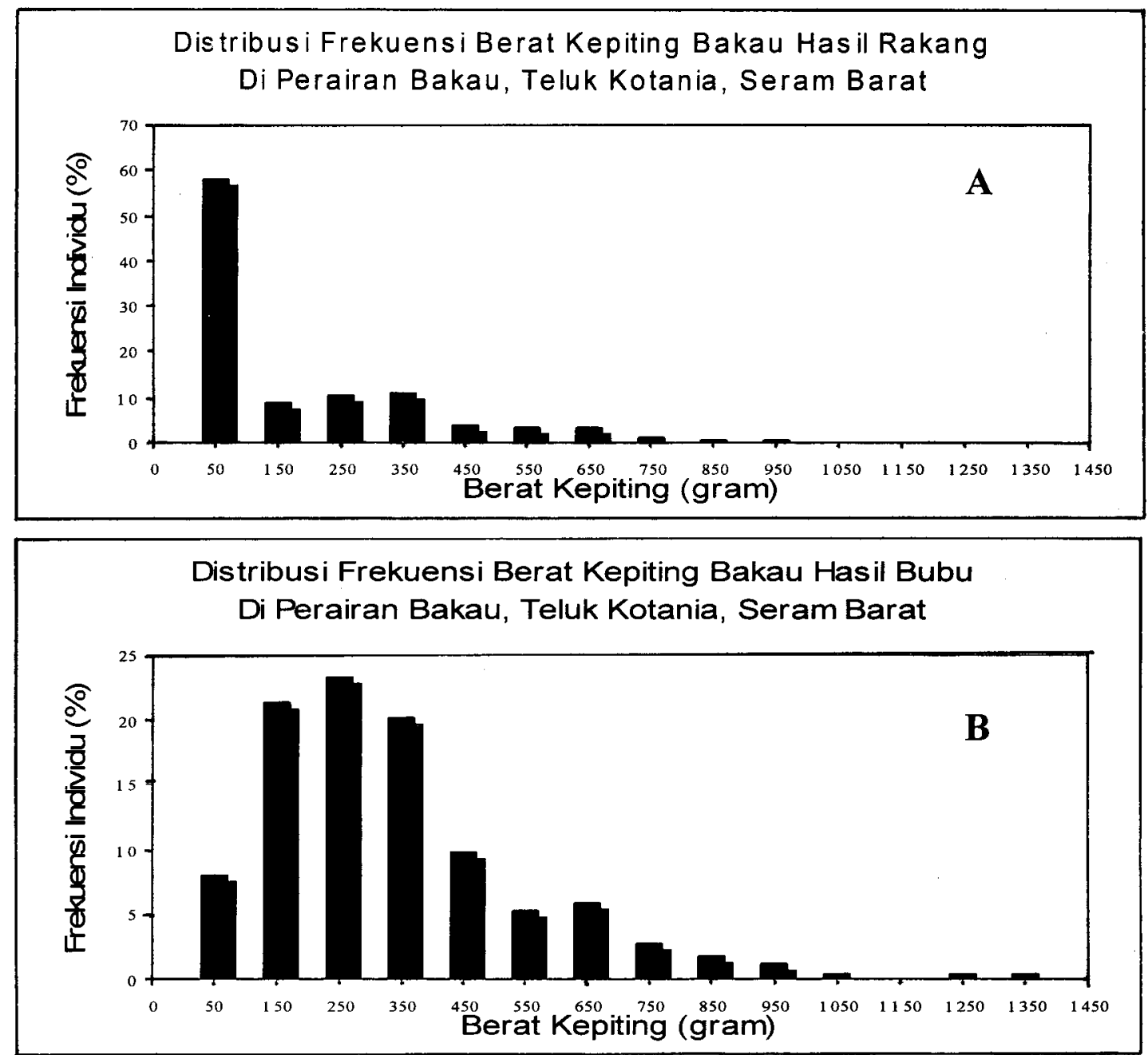

Gambar 2. Frekuensi distribusi berat badan kepiting bakau hasil tangkapan rakang $(A)$ dan bubu (B) di perairan bakau Teluk Kotania, Seram Barat, Maluku.

Figure 2. Weight frequency distribution of mud crabs from stick dip net catches (A) and pot catches (B) in mangrove areas of Kotania Bay, West Seram, Maluku.

(Portunus pelagicus). Hasil tangkapan jenis ini memiliki berat badan rata-rata $119 \pm 44 \mathrm{~g}$ dengan berat minimal $60 \mathrm{~g}$ dan maksimal $207 \mathrm{~g}$.

Kepiting kaniki (Thalamita danae) sangat melimpah di alam dan ditemukan di Wael dan sekitarnya. Statusnya belum dimanfaatkan. Ukuran berat badan terbesar yang terukur adalah $86 \mathrm{~g}$, di mana berat rata-rata badannya adalah $47 \pm 13 \mathrm{~g}$. Distribusi frekuensi ukuran berat badan kaniki disajikan pada Gambar 4.

Jika mengacu pada ukuran berat badan (Gambar 2) jelas bahwa hasil tangkapan rakang dapat digolongkan pada ukuran yang bernilai ekonomis lebih rendah dari hasil tangkapan bubu. Penggolongan ukuran ini ke dalam kelas ekonominya untuk wilayah Maluku dirincikan dalam Tabel 2.
Menurut Hill (1982), hasil tangkapan dengan bubu biasanya selalu berukuran besar, antara $50 \%$ sampai $85 \%$ memiliki lebar cangkang $15 \mathrm{~cm}$ dan ini merupakan ukuran kepiting legal yang dapat diperdagangkan. Sedangkan grafik batang pada Gambar 2 menunjukkan bahwa kurang lebih $70 \%$ hasil tangkapan rakang masih berukuran kecil (18-150 g), sedangkan untuk ukuran yang relatif sama dari hasil tangkapan bubu, $66-150 \mathrm{~g}$, adalah $30 \%$. Hal ini menunjukkan bahwa hasil tangkapan rakang lebih banyak jumlah individunya, tetapi ukuran bobot tubuh individual atau keseluruhannya jauh lebih rendah dibanding bobot tubuh individual atau keseluruhan dari hasil tangkapan bubu.

Dari Gambar 2 diketahui bahwa hasil tangkapan ke dua alat yang masuk kelompok ukuran super 1 $(3,8 \%)$ dan $\|(13,9 \%)$ terlihat jauh lebih sedikit dari 

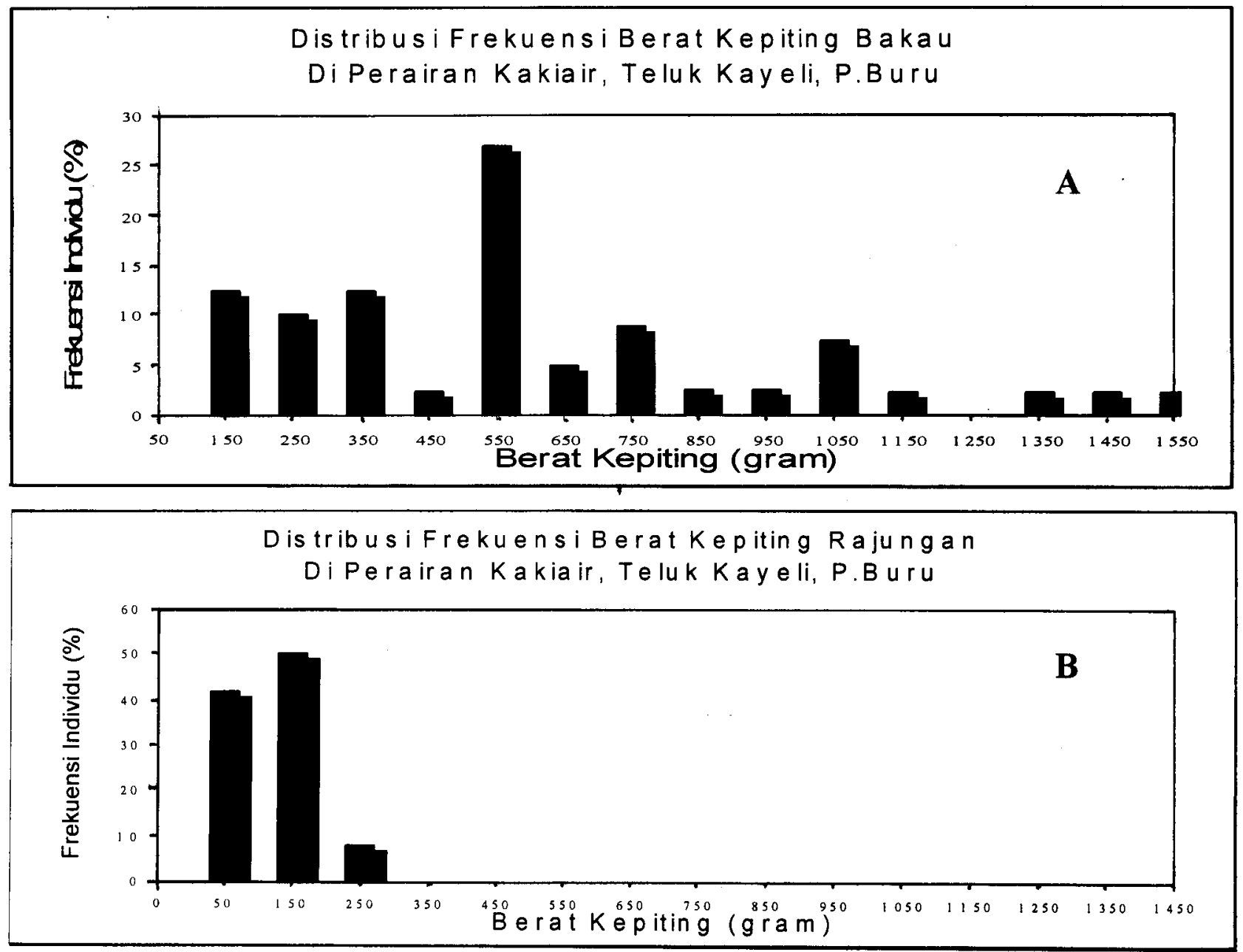

Gambar 3. Frekuensi distribusi berat badan kepiting bakau (A) dan rajungan (B) dari hasil tangkapan rakang di perairan bakau Teluk Kayeli, Pulau Buru, Maluku.

Figure 3. Weight frequency distributions of mud crabs (A) and rajungan (B) from stick dip net catches in mangrove areas of Kayeli Bay, Buru Island, Maluku.

Tabel 2. Ukuran layak jual dalam tata niaga kepiting bakau di Maluku

Table 2. The marketable sizes of mud crab in the local market of Maluku

\begin{tabular}{ccc}
\hline $\begin{array}{c}\text { Kelas Ukuran Ekonomis } \\
\text { (Economical Sizes) }\end{array}$ & $\begin{array}{c}\text { Interval } \\
\text { (Gram) }\end{array}$ & $\begin{array}{c}\text { Harga (Prices) } \\
\text { (Rp/kg) }\end{array}$ \\
\hline Super I & $>800$ & $>7.500,-$ \\
Super II & $500-799$ & $6.500,-$ \\
Kelas III & $300-499$ & $4.500,-$ \\
Kelas IV & $<299$ & $<3.000,-$ \\
\hline
\end{tabular}

ukuran kelas III dan IV. Karena ukuran-ukuran super umumnya ada pada betina, cangkangnya selalu lebih besar dari yang ada pada jantan, maka kurangnya ukuran super ini mungkin disebabkan oleh adanya ruaya kepiting betina matang ke laut untuk melakukan pemijahan. Sebagaimana diketahui bahwa setelah melakukan perkawinan kepiting bakau melakukan ruaya ke laut untuk bertelur (Anonimous, 1989). Pada saat percobaan penangkapan ini, beberapa tangkapan bubu yang berukuran super merupakan betina matang yang sedang mengandung telurnya.

\section{Produksi (Hasil Tangkapan)}

Hasil tangkapan menurut lokasi penangkapan dan alat tangkap disajikan pada Tabel 3.

Selama 64 hari operasi penangkapan dengan rakang, yaitu sebanyak 124 kali tawur (setting), diperoleh total produksi 378 ekor atau setara dengan $62,6 \mathrm{~kg}$, di mana $14,25 \%$ adalah tergolong non komersil. Dari jumlah tersebut $\pm 70 \%$ berukuran kecil antara $18-150$ g. Sementara dari hasil tangkapan 


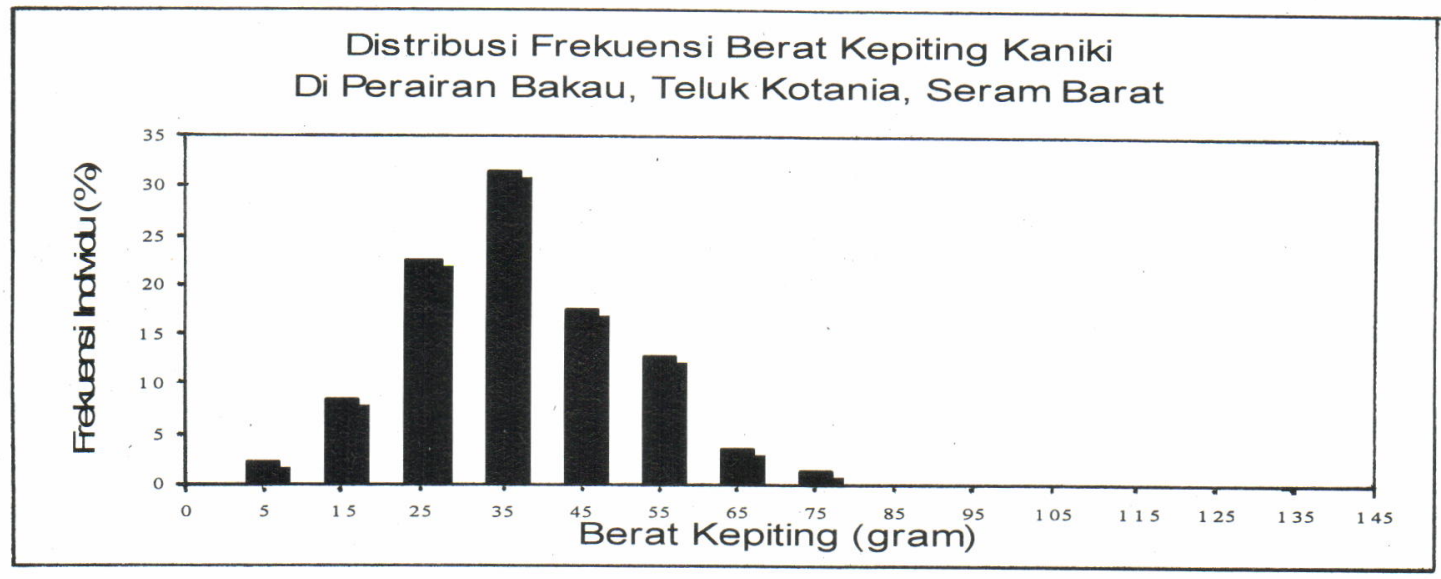

Gambar 4. Frekuensi distribusi berat badan kepiting kaniki hasil tangkapan rakang di perairan bakau Teluk Kotania, Seram Barat, Maluku.

Figure 4. Weight frequencies distribution of kanikis from stick dip net catches in mangrove areas of Kotania Bay, West Seram, Maluku.

Tabel 3. Hasil tangkapan kepiting menurut lokasi, jenis kepiting, dan alat tangkap

Table 3. Crab yields listed by fishing grounds, species, and gears

\begin{tabular}{|c|c|c|c|c|c|c|}
\hline \multirow{4}{*}{$\begin{array}{l}\text { Lokasi Penangkapan } \\
\text { (Fishing Gronds) }\end{array}$} & \multicolumn{6}{|c|}{ Hasil Tangkapan (Yields) } \\
\hline & \multicolumn{4}{|c|}{ Rakang (Stick Dip Nets) } & \multirow{2}{*}{\multicolumn{2}{|c|}{$\begin{array}{c}\text { Bubu (Trap pots) } \\
\text { Kepiting Bakau } \\
\text { (Scylla spp) }\end{array}$}} \\
\hline & \multicolumn{2}{|c|}{$\begin{array}{c}\text { Kepiting Bakau } \\
\text { (Scylla spp) }\end{array}$} & \multicolumn{2}{|c|}{$\begin{array}{l}\text { Kepiting Kaniki } \\
\text { (Thalamita denae) }\end{array}$} & & \\
\hline & Individual & Gram & Individual & Gram & Individual & Gram \\
\hline Nipa (Masikajaya) & 75 & 24.521 & 63 & 2.916 & 56 & 20.765 \\
\hline Matahelut (Masikajaya) & 28 & 8.143 & 5 & 247 & 39 & 13.343 \\
\hline Hatileng (Masikajaya) & 2 & 825 & 4 & 190 & 5 & 1.525 \\
\hline Nipa Lupesi (Tamanjaya) & 0 & 0 & 0 & 0 & 10 & 1.622 \\
\hline Telaga Salema (Tamanjaya) & 11 & 1.959 & 70 & 3.184 & 6 & 1.465 \\
\hline Mau-mau (Wael) & 3 & 194 & 4 & 164 & 0 & 0 \\
\hline Hatuya (Wael) & 4 & 652 & 3 & 159 & 0 & 0 \\
\hline Kepala Telaga (Wael) & 3 & 1.018 & 4 & 246 & 12 & 3.032 \\
\hline Pantai Rahasia (Wael) & 6 & 2.969 & 16 & 689 & 4 & 889 \\
\hline Pantai Rahasia (Kotania) & 5 & 1.023 & 8 & 306 & & \\
\hline Pagar-pagar (Kotania) & 6 & 2.524 & 6 & 312 & & \\
\hline Laheba (Kotania) & 8 & 1.823 & 5 & 283 & & \\
\hline Waihutu (Kotania) & 11 & 3.887 & 5 & 234 & & \\
\hline \multirow[t]{2}{*}{ Saaru Lima (Kakiair) } & 11 & 2.752 & $12^{\star}$ & $1.429^{*}$ & & \\
\hline & 173 & 52.289 & 205 & 10.356 & 132 & 42.640 \\
\hline
\end{tabular}

* Kepiting rajungan (Portunus pelagicus)

bubu selama 23 hari operasi dengan 183 kali pasang dihasilkan 132 ekor atau setara dengan $42,64 \mathrm{~kg}$, tetapi hanya $\pm 30 \%$ dari jumlah tersebut yang berukuran kecil, yaitu antara 66-150 g. Karena faktor ukuran ini produksi dari rakang lebih rendah dari produksi bubu.

Rendahnya produksi rakang ini disebabkan oleh tingginya angka kelolosan di saat penarikan (hauling). Tingkat kehilangan hasil ini semula 50\%, tetapi setelah penangkap lebih terampil dan alat tangkap sedikit dimodifikasi (memperkecil mata jaring), tingkat kelolosan menurun menjadi $12-16 \%$. Dari pengalaman ini jelas bahwa perikanan kepiting bakau memerlukan penangkap-penangkap yang terampil, terlebih untuk menangkap kepiting-kepiting yang berukuran besar. Dengan demikian, produksi sangat ditentukan oleh keterampilan penangkap, baik keterampilan menentukan daerah tangkapan maupun keterampilan dalam hauling.

Rakang dioperasikan secara aktif dengan cara menancapkan tongkat penyanggahnya ke dasar perairan dan mengangkatnya ketika umpan dimakan, kemudian memasangnya kembali seperti semula dan seterusnya berulang kali selama 3 sampai 4 jam dari mulai pasang naik sampai puncak pasang, sedangkan bubu dioperasikan secara pasif dengan cara membenamkan ke dasar perairan dan meninggalkan selama 24 jam di area tangkapan. Oleh karena itu, kelimpahan sumber daya sangat menentukan jumlah hasil tangkapan. Di lokasi-lokasi yang kelimpahan 
sumber dayanya lebih besar ternyata bahwa rakang mampu menghasilkan lebih besar dalam waktu yang singkat. Seperti misalnya terjadi di Kolam Nipa Masikajaya dan Telaga Salema Tamanjaya. Menurut nelayan Kakiair yang pernah menggunakan rakang, penangkapan di lokasi yang belum tereksploitasi pada tahun 1995 menghasilkan satu ekor/unit rakang/trip. Tetapi jumlahnya semakin menurun pada tahun-tahun berikutnya. Dari hasil percobaan Mallawa (1991) di perairan muara Sungai Tamuku, Bone-bone, dan Batang Tongka, Sulawesi Selatan, diketahui bahwa rata-rata hasil tangkapan rakang selama 25 trip adalah 1-3,3 ekor/unit rakang/trip dengan interval berat antara 130-160 gam.

\section{Produktivitas Alat Tangkap}

Produktivitas tangkapan dengan rakang dikelompokkan dalam jumlah penggunaan unit rakang per nelayan, mulai dari 50 unit, 40 unit, dan 30 unit tiap nelayan. Pengelompokan ini untuk melihat optimalisasi penggunaan jumlah rakang per penangkap. Tabel 4 menunjukkan bahwa CPUE rakang berkisar antara 1,1-37,0 g/unit alat/trip/ nelayan, dengan rata-rata $17 \mathrm{~g} / \mathrm{unit}$ alat/trip/nelayan. Sementara Tabel 5 menunjukkan produktivitas alat tangkap bubu. Dari 183 kali pasang bubu (setting selama 24 jam) diperoleh nilai CPUE rata-rata 120 g/unit alat/trip/nelayan.

Tabel 4

Produktivitas alat tangkap rakang

Table 4 Stick dip net's productivity

\begin{tabular}{|c|c|c|c|c|c|c|}
\hline \multirow[b]{2}{*}{$\begin{array}{l}\text { Operator } \\
\text { (Fishers) }\end{array}$} & \multicolumn{2}{|l|}{ Jumlah } & \multicolumn{2}{|c|}{ Produksi (Yields) } & \multirow[b]{2}{*}{$\begin{array}{c}\text { Jumlah } \\
\text { Produksi } \\
\text { (Total Yield) }\end{array}$} & \multirow[b]{2}{*}{ CPUE* $^{\star}$} \\
\hline & $\begin{array}{c}\text { Alat } \\
\text { (Gears) }\end{array}$ & $\begin{array}{l}\text { Hari Operasi } \\
\text { (Fishing Trips) }\end{array}$ & $\begin{array}{l}\text { Kepiting Bakau } \\
\text { (Scylla spp.) }\end{array}$ & $\begin{array}{c}\text { Kepiting Kaniki } \\
\text { (Thalamita denae) }\end{array}$ & & \\
\hline 3 & 150 & 10 & $4.369 \mathrm{~g}$ & $769 \mathrm{~g}$ & $5.138 \mathrm{~g}$ & $1,1^{*}$ \\
\hline 3 & 120 & 10 & $5.046 \mathrm{~g}$ & $659 \mathrm{~g}$ & $5.704 \mathrm{~g}$ & $1,6^{\star}$ \\
\hline 2 & 60 & 10 & $6.724 \mathrm{~g}$ & $4.887 \mathrm{~g}$ & $11.611 \mathrm{~g}$ & $9,7^{*}$ \\
\hline 2 & 60 & 10 & $19.098 \mathrm{~g}$ & $740 \mathrm{~g}$ & $19.838 \mathrm{~g}$ & $16,5^{*}$ \\
\hline 1 & 30 & 10 & $4.284 \mathrm{~g}$ & $797 \mathrm{~g}$ & $5.081 \mathrm{~g}$ & $16,9^{*}$ \\
\hline 1 & 30 & 4 & $2.752 \mathrm{~g}$ & $1.429 \mathrm{~g}$ & $4.181 \mathrm{~g}$ & $34,8^{*}$ \\
\hline 1 & 30 & 10 & $10.017 \mathrm{~g}$ & $1.075 \mathrm{~g}$ & $11.092 \mathrm{~g}$ & $37,0^{*}$ \\
\hline \multicolumn{3}{|c|}{ Jumlah (Total) } & $52.289 \mathrm{~g}$ & $10.356 \mathrm{~g}$ & $62.645 \mathrm{~g}$ & $\begin{array}{c}\text { Rata-rata } \\
\text { (Average) } \\
17^{*} \\
\end{array}$ \\
\hline
\end{tabular}

Tabel 5. Produktivitas alat tangkap bubu

Table 5. Trap-pot's productivity

\begin{tabular}{|c|c|c|c|c|c|c|}
\hline \multirow[b]{2}{*}{$\begin{array}{l}\text { Operator } \\
\text { (Fishers) }\end{array}$} & \multicolumn{2}{|l|}{ Jumlah } & \multicolumn{2}{|c|}{ Produksi (Yields) } & \multirow[b]{2}{*}{$\begin{array}{c}\text { Jumlah } \\
\text { Produksi } \\
\text { (Total Yield) }\end{array}$} & \multirow[b]{2}{*}{ CPUE* } \\
\hline & $\begin{array}{c}\text { Alat } \\
\text { (Gears) }\end{array}$ & $\begin{array}{l}\text { Hari Operasi } \\
\text { (Fishing } \\
\text { Trips) }\end{array}$ & $\begin{array}{l}\text { Kepiting Bakau } \\
\text { (Scylla spp.) }\end{array}$ & $\begin{array}{c}\text { Kepiting Kaniki } \\
\text { (Thalamita denae) }\end{array}$ & & \\
\hline 2 & 7 & 5 & $10.419 \mathrm{~g}$ & 0 & $10.419 \mathrm{~g}$ & $149,0^{*}$ \\
\hline 2 & 8 & 6 & $11.566 \mathrm{~g}$ & 0 & $11.566 \mathrm{~g}$ & $120,5^{\star}$ \\
\hline 2 & 6 & 5 & $6.904 \mathrm{~g}$ & 0 & $6.904 \mathrm{~g}$ & $115,0^{*}$ \\
\hline 2 & 10 & 7 & $13.751 \mathrm{~g}$ & 0 & $13.751 \mathrm{~g}$ & 98,0 * \\
\hline \multicolumn{3}{|c|}{ Jumlah (Total) } & & & $42.640 \mathrm{~g}$ & $\begin{array}{r}\text { Rata-rata } \\
\text { (Average) } \\
120,6^{*} \\
\end{array}$ \\
\hline
\end{tabular}

Analisis pada Tabel 4 menunjukkan bahwa pengurangan jumlah unit rakang tidak mempengaruhi produksi, karena nilai CPUE tetap meningkat. Hal ini dapat dimengerti karena pengoperasian rakang bersifat aktif dan tidak menjerat (trapped). Karena itu penggunaan jumlah unit rakang yang terlampau besar per penangkap tidak efektif karena memperluas kawasan area penangkapan. Luasnya jarak penangkapan akan menyulitkan pengawasan. Jadi jumlah yang optimal untuk digunakan dalam penangkapan kepiting bakau dianjurkan antara 20 sampai 30 unit per nelayan.

Perbedaan prinsipil antara bubu dan rakang dalam aspek prosedur operasional adalah bahwa rakang membutuhkan lebih banyak keterampilan dibanding dengan operasional bubu. Karena itu berdasarkan nilai produktivitas masing-masing alat, jelas bahwa 
alat tangkap bubu masih lebih produktif dibanding rakang. Kemampuan produksi rakang dibandingkan dengan bubu diperkirakan kurang dari 50\%. Untuk tujuan pengumpulan benih alam, seperti misalnya untuk keperluan budi daya, rakang layak digunakan karena (jumlah individu) hasilnya tinggi. Untuk meningkatkan produksi dalam pengertian ukuran biomassa, modifikasi alat sangat dianjurkan di samping adanya anjuran untuk melakukan latihan penangkapan. Modifikasi alat rakang mungkin dapat dianjurkan dengan spesifikasi lingkaran primer lebih besar dengan posisi jaring lebih mengkerucut.

Untuk melengkapi informasi tersebut sebaiknya juga ditemukan pembanding dalam hal kemampuan produksi rakang. Penelitian Gunarto et al., (1997) pada periode bulan Juni-September 1997 menunjukkan bahwa hasil penangkapan kepiting bakau dengan rakang di muara Sungai Cenranae Kabupaten Bone, Sulawesi Selatan, menghasilkan rata-rata 25 ekor/hari/nelayan dengan nilai CPUE 44,26 g/unit alat/hari. Nilai CPUE ini tentu saja merupakan refleksi dari hasil tangkapan nelayannelayan yang sudah mahir dan terbiasa menggunakan rakang, di mana dalam 85 hari operasi dengan menggunakan 40 unit rakang dihasilkan produksi total $150,5 \mathrm{~kg}$ kepiting bakau dengan interval ukuran antara 30-150 g.

\section{KESIMPULAN DAN SARAN}

\section{Kesimpulan}

1. Ada 4 jenis kepiting dan 1 rajungan yang diperoleh dari penggunaan rakang, yaitu kepiting kaniki (Thalmita danae), kepiting bakau merah (Scylla serrata), kepiting bakau hitam (Scylla oceanica), kepiting bakau hijau (Scylla tranquebarica), dan rajungan (Portunus pelagicus).

2. Sebagian besar $(70 \%)$ dari jumlah kepiting yang tertangkap oleh rakang adalah berukuran kecil dengan bobot tubuh berkisar antara 18-150 g, sedangkan jumlah kepiting yang tertangkap oleh bubu pada interval bobot tubuh tersebut hanya $30 \%$.

3. Produksi rakang dalam 64 trip penangkapan sebesar $62,6 \mathrm{~kg}$, terdiri dari 378 ekor dengan interval berat badan antara $18-924 \mathrm{~g}$. Produksi bubu dalam 23 trip penangkapan sebesar 42,64 $\mathrm{kg}$, terdiri dari 132 ekor dengan interval berat badan antara 66-1.349 g. Jadi tangkapan bubu menunjukkan lebih banyak individu-individu yang memiliki bobot tubuh lebih besar dari yang dihasilkan tangkapan rakang.

4. Produktivitas atau CPUE rakang rata-rata $17 \mathrm{~g} / \mathrm{unit}$ alat/trip/nelayan, sementara untuk bubu adalah 120 g/unit alat/trip/nelayan. Jadi tingkat produktivitas rakang relatif lebih rendah dibanding produktivitas bubu.
Saran

1. Rakang dapat dimanfaatkan untuk penangkapan anakan kepiting bakau untuk tujuan pengumpulan dan pembesaran kepiting bakau.

2. Rakang dapat digunakan sebagai alat tangkap utama, di samping bubu, dalam perikanan kepiting bakau di Maluku yang memiliki lahan mangrove yang tersebar luas, terutama sekali baik digunakan untuk penangkapan dengan trip yang jauh dan membutuhkan waktu lama. Selain itu rakang juga praktis dan tidak menggunakan tempat yang luas untuk dibawa jauh.

3. Perlu dilakukan percobaan berulang-ulang dengan alat tangkap rakang untuk memastikan tingkat keterampilan nelayan dan produktivitas rakang pada lokasi-lokasi yang memiliki sumber daya kepiting bakau yang melimpah.

4. Perlu dilakukan modifikasi alat, terutama memperbesar lingkaran rangka jala, memperdalam bentuk kerucut jala, dan memperkecil mata jala.

\section{DAFTAR PUSTAKA}

Afrianto, E. \& E. Liviawaty. 1992. Pemeliharaan kepiting. Penerbit Kanisius, Jogyakarta, h. 25.

Anonimous. 1989. Bulletin warta mina. Media Informasi dan Komunikasi Perikanan, Jakarta, No.: 21:12-15.

Edrus, I.N. \& S. Bustaman. 1998. The Kotania Bay mud crab fishery. Work Paper. Balai Pengkajian Teknologi Pertanian, Ambon (unpublished).

Gunarto \& I. Rusdi. 1993. Budi daya kepiting bakau, Scylla serrata, di tambak pada padat penebaran berbeda. Jurnal Penelitian Budidaya Pantai, Vol 9 (3): 7-12.

Gunarto, R. Daud, Utojo, \& A. Hanafi. 1997. Pemanfaatan dan alternatif pengelolaan sumber daya kepiting bakau Scylla sp. di perairan muara Sungai Cenranae Kabupaten Bone Sulawesi Selatan. Laporan Penelitian, Balai Penelitian Perikanan Pantai, Maros, 12 hal (Unpublished).

Hill, B.J. 1982. The Queensland mud crab fishery. Queensland Fisheries Information Seri FI 8201. Fisheries Reseach Branch. Qld. Dept. of Primary Industries. Queensland Australia. P.24.

Mallawa, A. 1991. Penggunaan bubu piramid dalam penangkapan kepiting bakau Scylla serrata. Buletin IImu dan Teknologi Kelautan UNHAS: TORANI, Vol I (1): 30-45

Moosa, M.K. 1980. Beberapa catatan mengenai rajungan dari Teluk Jakarta dan Pulau-pulau 
Seribu. Sumber Daya Hayati Bahari, LON-LIPI Jakarta, 79 hal.

Moosa, M.K., I. Aswandy, \& A. Kasry. 1985. Kepiting Bakau, Scylla serrata (FORSSKAL, 1775) dari perairan Indonesia. Seri Sumber Daya Alam 122, LON-LIPI Jakarta, 17 hal.

Nontji, A. 1987. Laut Nusantara. Penerbit Djambatan, Jakarta, h. 105.

Sparre, P. \& S.C. Venema. 1992. Introduction to Tropical Fish Stock Assessment. Part I. Manual FAO Fish Tech. Paper No. 306 Rev I, Rome, 376 p.
Subani, W. \& H.R. Barus. 1989. Alat penangkapan ikan dan udang laut di Indonesia. Jurnal Peneletian Perikanan Laut. Edisi Khusus No. 50, 248 hal.

Wardoyo, S.E., A. Hanafi, \& E. Pratiwi. 1996. Status dan prospek pengembangan perikanan kepiting bakau di Kalimantan Barat. Warta Penelitian Perikanan Indonesia Vol 2 (1): 10-15.

Yunus. 1992. Pemeliharaan larva kepiting bakau, Scylla serrata dengan beda kepadatan retifera, Brachionus plicatilis. Jurnal Penelitian Budi Daya Pantai, Vol 8 (2): 9-14. 